\title{
Schiff bases of 4-(methylthio)benzaldehydes: Synthesis,characterization, antibacterial, antioxidant and cytotoxicity Studies
}

\author{
Chimatahalli S. Karthik ${ }^{a}$, Lingappa Mallesha ${ }^{b}$, Shivashankarappa Nagashree ${ }^{a}$, Puttaswamappa \\ Mallu $^{a^{*}}$, Vasanth Patil ${ }^{\mathfrak{c}}$ and Sathish Kumar
}

${ }^{a}$ Department of Chemistry, Sri Jayachamarajendra College of Engineering, Mysore 570 006, India ${ }^{b} P G$ Department of Chemistry, JSS College of Arts, Commerce and Science, Ooty Road, Mysore 570 025, India ${ }^{c} P G$ Department of Biotechnology, JSS College of Arts, Commerce and Science, Mysore 570 025, India

\begin{tabular}{l} 
C H R O N I C L E \\
\hline Article history: \\
Received July 21, 2015 \\
Received in revised form \\
August 29, 2015 \\
Accepted 4 December 2015 \\
Available online \\
4 December 2015 \\
\hline Keywords: \\
4-(Methylthio)benzaldehyde \\
Cytotoxicity \\
Antibacterial \\
Antioxidant
\end{tabular}

\section{Introduction}

4-(Methylthio)benzaldehyde is a essential moiety for the synthesis of various pharmaceutical and biologically active compounds. It is the intermediate for the synthesis of a pyrrole derivatives showing anti-inflammatory activity. ${ }^{1,2}$ Antimicrobial drug discovery research, accompanied by clinical development, has historically been conducted by large pharmaceutical companies. Infections caused by microbes are a serious menace to the health of human beings and often have connection to some other diseases, whenever the body system gets debilitated. The number of different classes of

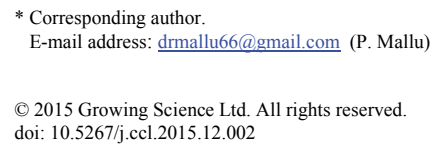


antibacterial $^{3,4}$ and antifungal agents ${ }^{5}$ has been discovered. The extensive use of antibiotics has led to the appearance of multi-drug resistant microbial pathogens. ${ }^{6}$

The compounds containing an imine groups are important in elucidating the mechanism of transamination and racemisation reactions in biological systems. ${ }^{7,8}$ Due to the great flexibility and diverse structural aspects, a wide range of Schiff bases have been synthesized and their complexation behaviors have been studied. ${ }^{9}$ They have been synthesized from a variety of compounds, such as amino thiazoles, 2-hydroxy-1-naphthalaniline, amino sugars, aromatic aldehydes, ketones, isatin, triazole ring, thiosemicarbazides, amino acids, pyrazolone, etc. ${ }^{10,11}$ Antimicrobial and anticancer activities of Schiff bases have been reported ${ }^{12}$ and they are active against a wide range of organisms. Many Schiff bases are known to be medicinally important and are used to design medicinal compounds. ${ }^{13}$

Free radical contains an odd number of electrons which makes it unstable, short lived and highly reactive. Therefore, it reacts quickly with other compounds in order to capture the needed electron to gain stability. Generally, free radical attacks the nearest stable molecule, stealing its electron. When the attacked molecule loses its electron, it becomes a free radical itself, beginning a chain reaction cascade resulting in disruption of a living cell. ${ }^{14,15}$ There are two basic categories of antioxidants, namely, synthetic and natural. In general, synthetic antioxidants are compounds with phenolic structures of various degrees of alkyl substitution, whereas natural antioxidants can be phenolic compounds, nitrogen compounds as well as ascorbic acid. ${ }^{16,17}$ The primary antioxidants comprise essentially sterically hindered phenols and secondary aromatic amines. ${ }^{18}$ These antioxidants act usually both through chain transfer and chain termination. The first step of the reactive radical's termination by this type of antioxidants is hydrogen atom transfer from the antioxidant molecule to the reactive radical intermediate. ${ }^{19}$ In general, water-soluble antioxidants react with oxidants in the cell cytosol and the blood plasma while lipid-soluble antioxidants protect cell membranes from lipid peroxidation. ${ }^{20}$ These compounds may be synthesized in the body or obtained from the diet. ${ }^{21}$ A significant part of drug discovery in the past few years has been focused on agents to prevent or treat cancer. This is not surprising because, in most developed countries and, to an increasing extent, cancer is among the three most common causes of death and morbidity. Cancer treatments may involve surgery, radiotherapy, and chemotherapy and often a combination of two or all three is employed. Cytotoxicity studies involve the analysis of morphological damage or inhibition of zone of outgrowth induced by the chemicals tested. ${ }^{22}$ The methods used for the evaluation of Cytotoxicity i.e. blue dye exclusion assay in that the tryphan blue was a vital stain used to selectively color dead tissues or cells blue based on the principle that live (viable) cells actively pump out the dye by efflux mechanism where as dead (nonviable) cells do not and MTT [(3-(4,5-dimethylthiazol-2yl)-2,5-diphenyltetrazoliumbromide] which measures the metabolic activity of the viable cells. ${ }^{23}$ In this respect, the present paper reports the synthesis and biological activities of a new class of Schiff bases of 4-(methylthio)benzaldehyde derivatives 3(a-i).

\section{Experimental}

\subsection{Chemistry}

All solvents and reagents were purchased from Sigma Aldrich Chemicals Pvt Ltd. Melting range was determined by Veego Melting Point VMP III apparatus. The UV-Visible spectrum was recorded on UV-1800 SHIMADZU UV spectrometer with quartz cell of $1.0 \mathrm{~cm}$ path length. An elemental analysis was recorded on Costech ECS 4010 CHNS-O Elemental Analyzer. The FT-IR spectra was recorded using $\mathrm{KBr}$ discs on FT-IR Jasco 4100 infrared spectrophotometer and were quoted in $\mathrm{cm}^{-1} .{ }^{1} \mathrm{H}$ NMR spectra was recorded on Bruker DMX 300, 400MHz spectrometer using DMSO- $\mathrm{d}_{6}$ as solvent and TMS as an internal standard. Mass spectral data were obtained by LC-MSD Trap XCT. Silica gel column chromatography was performed using Merck 7734 silica gel (60-120 mesh) and Merck-made TLC plates. 
2.2. General procedure for the synthesis of Schiff bases of 4-(methylthio)benzaldehyde derivatives (3a-i)

Equimolar concentrations of 4-(methylthio)benzaldehyde $(3.28 \mathrm{mmol}, \mathbf{1})$ and different amines (3.28 mmol, 2a-i) were refluxed for 7-8 hr using methanol (25 ml) and 2-3 drops of conc. sulfuric acid was added to the mixture. The progress of the reaction was followed by TLC until the reaction was complete. It was poured to ice cold water, the precipitate was filtered, washed with excess of distilled water and the residue was recrystallized from ethanol, DMF and ethyl acetate. Compounds 3(a-i) were prepared by the method summarized in Scheme 1.

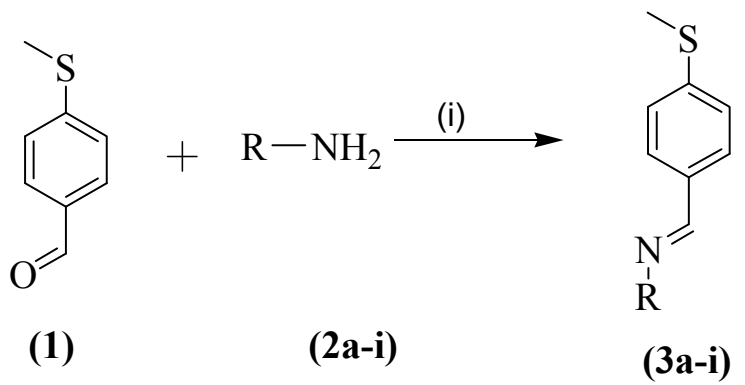

Scheme 1 Reagents and conditions: (i) Methanol, reflux, $\mathrm{H}^{+}, 7-8 \mathrm{hr}$

\subsection{1.(E)-N-(4-(Methylthio)benzylidene)-3,5-dibromopyrazin-2-amine (3a)}

The product was synthesized by the reaction of 1 and 3,5-dibromopyrazin-2-amine (2a). It was obtained as a yellow solid. FT-IR $\left(\mathrm{KBr}, \mathrm{cm}^{-1}\right)$ : $3078(\mathrm{Ar}-\mathrm{H}), 1671(\mathrm{HC}=\mathrm{N}), 1468(\mathrm{C}=\mathrm{C}), 1298(\mathrm{C}-\mathrm{S})$, 527 (C-Br). ${ }^{1} \mathrm{H}$ NMR (DMSO-d $) \delta$ ppm: 2.39 (s, 3H, $\left.\mathrm{CH}_{3}\right), 7.23$ (d, 2H, Ar-H), 7.61 (d, 2H, Ar-H), $7.98(\mathrm{~s}, 1 \mathrm{H}, \mathrm{CH}=\mathrm{N}), 8.81$ (s, $1 \mathrm{H}$, Pyrazine-H). MS (ESI) $m / z$ : 387.80. Anal. Calcd. for $\mathrm{C}_{12} \mathrm{H}_{9} \mathrm{Br}_{2} \mathrm{~N}_{3} \mathrm{~S}$ (in \%): C, 37.23; H, 2.34; N, 10.86. Found: C, 37.20; H, 2.10; N, 10.91 .

\subsection{2. (E)-2-(4-(Methylthio)benzylideneamino)-6-methylpyrimidin-4-ol (3b)}

The product was synthesized by the reaction of 1 and 2-amino-6-methylpyrimidin-4-ol (2b). It was obtained as a white solid. FT-IR $\left(\mathrm{KBr}, \mathrm{cm}^{-1}\right): 3514(\mathrm{O}-\mathrm{H}), 3059(\mathrm{Ar}-\mathrm{H}), 1660(\mathrm{HC}=\mathrm{N}), 1454$ $(\mathrm{C}=\mathrm{C}), 1331(\mathrm{C}-\mathrm{S}) .{ }^{1} \mathrm{H}$ NMR $\left(\mathrm{DMSO}_{-} \mathrm{d}_{6}\right) \delta \mathrm{ppm}: 2.35\left(\mathrm{~s}, 3 \mathrm{H}, \mathrm{CH}_{3}\right), 2.46\left(\mathrm{~s}, 3 \mathrm{H}, \mathrm{CH}_{3}\right), 5.20(\mathrm{~s}, 1 \mathrm{H}$, $\mathrm{OH}), 6.71(\mathrm{~s}, 1 \mathrm{H}, \mathrm{Ar}-\mathrm{H}), 7.29$ (d, 2H, Ar-H), 7.69 (d, 2H, Ar-H), $8.01(\mathrm{~s}, 1 \mathrm{H}, \mathrm{CH}=\mathrm{N})$. MS (ESI) $m / z$ : 260.11. Anal. Calcd. for $\mathrm{C}_{13} \mathrm{H}_{13} \mathrm{~N}_{3} \mathrm{OS}$ (in \%): C, 60.21; H, 5.05; N, 16.20. Found: C, 60.18; H, 5.28; N, 16.12 .

\subsection{3. (E)-N-(4-(Methylthio)benzylidene)-4-bromo-2-chloro-6-methylbenzenamine (3c)}

The product was synthesized by the reaction of 1 and 4-bromo-2-chloro-6-methylbenzenamine (2c). It was obtained as a white solid. FT-IR $\left(\mathrm{KBr}, \mathrm{cm}^{-1}\right): 3061(\mathrm{Ar}-\mathrm{H}), 1661(\mathrm{HC}=\mathrm{N}), 1468(\mathrm{C}=\mathrm{C})$, 1291 (C-S), 728 (C-Cl), 521 (C-Br). ${ }^{1} \mathrm{H}$ NMR (DMSO-d $) \delta$ ppm: 2.34 (s, 3H, $\left.\mathrm{CH}_{3}\right), 2.42\left(\mathrm{~s}, 3 \mathrm{H}, \mathrm{CH}_{3}\right)$, 7.20-7.61 (m, 6H, Ar-H), $8.29(\mathrm{~s}, 1 \mathrm{H}, \mathrm{CH}=\mathrm{N})$. MS (ESI) $\mathrm{m} / \mathrm{z}$ : 355.41. Anal. Calcd. for $\mathrm{C}_{15} \mathrm{H}_{13} \mathrm{BrClNS}$ (in \%): C, 50.79; H, 3.69; N, 3.95. Found: C, 50.83; H, 3.71; N, 3.72.

\subsection{4. (E)-N-(4-(Methylthio)benzylidene)thiazol-2-amine (3d)}

The product was synthesized by the reaction of $\mathbf{1}$ and thiazol-2-amine (2d). It was obtained as an off white solid. FT-IR $\left(\mathrm{KBr}, \mathrm{cm}^{-1}\right): 3083(\mathrm{Ar}-\mathrm{H}), 1665(\mathrm{C}=\mathrm{N}), 1474(\mathrm{C}=\mathrm{C}), 1310(\mathrm{C}-\mathrm{S}) .{ }^{1} \mathrm{H}$ NMR (DMSO-d $)_{6} \delta$ ppm: $2.31\left(\mathrm{~s}, 3 \mathrm{H}, \mathrm{CH}_{3}\right), 7.11(\mathrm{~d}, 1 \mathrm{H}$, thiazole-H), $7.24(\mathrm{~d}, 2 \mathrm{H}, \mathrm{Ar}-\mathrm{H}), 7.63(\mathrm{~d}, 2 \mathrm{H}, \mathrm{Ar}-$ $\mathrm{H}), 7.92\left(\mathrm{~d}, 1 \mathrm{H}\right.$, thiazole-H), $8.78(\mathrm{~s}, 1 \mathrm{H}, \mathrm{CH}=\mathrm{N})$. MS (ESI) $m / z: 235.40$. Anal. Calcd. for $\mathrm{C}_{11} \mathrm{H}_{10} \mathrm{~N}_{2} \mathrm{~S}_{2}$ (in \%): C, 56.38; H, 4.30; N, 11.95. Found: C, 56.42; H, 4.12; N, 11.71. 


\subsection{5. (E)-5-(4-(Methylthio)benzylideneamino)-1,3,4-thiadiazole-2-thiol (3e)}

The product was synthesized by the reaction of 1 and 5-amino-1,3,4-thiadiazole-2-thiol (2e). It was obtained as a white solid. FT-IR $\left(\mathrm{KBr}, \mathrm{cm}^{-1}\right)$ : $3014(\mathrm{Ar}-\mathrm{H}), 2589(\mathrm{~S}-\mathrm{H}), 1659(\mathrm{C}=\mathrm{N}), 1453(\mathrm{C}=\mathrm{C})$, $1328(\mathrm{C}-\mathrm{S}) .{ }^{1} \mathrm{H}$ NMR (DMSO-d $\left.{ }_{6}\right) \delta$ ppm: 2.40 (s, 3H, $\left.\mathrm{CH}_{3}\right), 2.81(\mathrm{~s}, 1 \mathrm{H}, \mathrm{S}-\mathrm{H}), 7.25$ (d, 2H, Ar-H), 7.65 $(\mathrm{d}, 2 \mathrm{H}, \mathrm{Ar}-\mathrm{H}), 8.49$ (s, $1 \mathrm{H}, \mathrm{CH}=\mathrm{N})$. MS (ESI) $\mathrm{m} / \mathrm{z}$ : 267.98. Anal. Calcd. for $\mathrm{C}_{10} \mathrm{H}_{9} \mathrm{~N}_{3} \mathrm{~S}_{3}$ (in \%): $\mathrm{C}, 44.92$; H, 3.39; N, 15.71. Found: C, 44.80; H, 3.10; N, 15.84 .

\subsection{6. (E)-N-(4-(Methylthio)benzylidene)-4-chloropyridin-2-amine (3f)}

The product was synthesized by the reaction of $\mathbf{1}$ and 4-chloropyridin-2-amine (2f). It was obtained as a white solid. FT-IR $\left(\mathrm{KBr}, \mathrm{cm}^{-1}\right)$ : $3020(\mathrm{Ar}-\mathrm{H}), 1670(\mathrm{C}=\mathrm{N}), 1440(\mathrm{C}=\mathrm{C}), 1328(\mathrm{C}-\mathrm{S}), 714$ (C-Cl). ${ }^{1} \mathrm{H}$ NMR (DMSO-d 6 ) $\delta$ ppm: 2.31 (s, 3H, $\left.\mathrm{CH}_{3}\right), 7.19$ (d, 2H, Ar-H), 7.69 (d, 2H, Ar-H), 7.41$8.69(\mathrm{~m}, 3 \mathrm{H}, \mathrm{Py}-\mathrm{H}), 8.55(\mathrm{~s}, 1 \mathrm{H}, \mathrm{CH}=\mathrm{N})$. MS (ESI) $\mathrm{m} / \mathrm{z}$ : 263.53. Anal. Calcd. for $\mathrm{C}_{13} \mathrm{H}_{11} \mathrm{ClN}_{2} \mathrm{~S}$ (in \%): C, 59.42; H, 4.22; N, 10.66. Found: C, 59.45; H, 4.26; N, 10.69.

\subsection{7. (E)-N-(4-(Methylthio)benzylidene)-3-chloro-5-(trifluoromethyl)pyridin-2-amine (3g)}

The product was synthesized by the reaction of 1 and 3-chloro-5-(trifluoromethyl)pyridin-2amine (2g). It was obtained as a white solid. FT-IR $\left(\mathrm{KBr}, \mathrm{cm}^{-1}\right): 3021(\mathrm{Ar}-\mathrm{H}), 1676(\mathrm{C}=\mathrm{N}), 1449$ $(\mathrm{C}=\mathrm{C}), 1309(\mathrm{C}-\mathrm{S}), 1106(\mathrm{C}-\mathrm{F}), 718(\mathrm{C}-\mathrm{Cl}) .{ }^{1} \mathrm{H}$ NMR (DMSO-d $) \delta$ ppm: 2.47 (s, 3H, $\left.\mathrm{CH}_{3}\right), 7.28(\mathrm{~d}$, 2H, Ar-H), 7.81 (d, 2H, Ar-H), 8.12 (s, 1H, Py-H), 8.32 (s, 1H, CH=N), 8.85 (s, 1H, Py-H). MS (ESI) $m / z$ : 331.36. Anal. Calcd. for $\mathrm{C}_{14} \mathrm{H}_{10} \mathrm{ClF}_{3} \mathrm{~N}_{2} \mathrm{~S}$ (in \%): C, 50.84; H, 3.05; N, 8.47 Found: C, 50.68; H, $3.24 ; \mathrm{N}, 8.51$.

\subsection{8. (E)-N $N^{1}$-(4-(Methylthio)benzylidene)-4-methyl-N3-(4-(pyridin-4-yl)pyrimidin-2yl)benzene-1,3-} diamine (3h)

The product was synthesized by the reaction of 1 and 6-methyl- $N^{I}$-(4-(pyridin-4-yl)pyrimidin-2yl)benzene-1,3-diamine (2h). It was obtained as a brownish white solid. FT-IR $\left(\mathrm{KBr}, \mathrm{cm}^{-1}\right): 3162(\mathrm{~N}-$ $\mathrm{H}), 3074(\mathrm{Ar}-\mathrm{H}), 1660(\mathrm{C}=\mathrm{N}), 1456(\mathrm{C}=\mathrm{C}), 1327(\mathrm{C}-\mathrm{S}), 1150(\mathrm{C}-\mathrm{N}) .{ }^{1} \mathrm{H}$ NMR $($ DMSO-d 6$) \delta$ ppm: 2.13 $\left(\mathrm{s}, 3 \mathrm{H}, \mathrm{CH}_{3}\right), 2.42\left(\mathrm{~s}, 3 \mathrm{H}, \mathrm{CH}_{3}\right), 6.58(\mathrm{~d}, 1 \mathrm{H}, \mathrm{Ar}-\mathrm{H}), 6.98(\mathrm{~d}, 1 \mathrm{H}, \mathrm{Ar}-\mathrm{H}), 7.11(\mathrm{~s}, 1 \mathrm{H}, \mathrm{Ar}-\mathrm{H}), 7.23(\mathrm{~d}$, $2 \mathrm{H}, \mathrm{Ar}-\mathrm{H}), 7.41-7.31(\mathrm{~d}, 2 \mathrm{H}$, pyrimidine-H), $7.55(\mathrm{t}, 1 \mathrm{H}$, pyridine- $\mathrm{H}), 7.80(\mathrm{~d}, 2 \mathrm{H}, \mathrm{Ar}-\mathrm{H}), 8.11(\mathrm{~s}, 1 \mathrm{H}$, $\mathrm{CH}=\mathrm{N}), 8.49(\mathrm{~d}, 1 \mathrm{H}$, pyridine-H), $8.70(\mathrm{~d}, 1 \mathrm{H}$, pyridine-H), $8.77(\mathrm{~s}, 1 \mathrm{H}$, pyridine-H), $9.23(\mathrm{~s}, 1 \mathrm{H}, \mathrm{N}-$ H). MS (ESI) $m / z$ : 412.07. Anal. Calcd. for $\mathrm{C}_{24} \mathrm{H}_{21} \mathrm{~N}_{5} \mathrm{~S}$ (in \%): C, 70.05; H, 5.14; N, 17.02. Found: $\mathrm{C}$, $70.14 ; \mathrm{H}, 5.30 ; \mathrm{N}, 17.26$.

\subsection{9. (E)-(4-(Methylthio)benzylidene)-3-(2-methyl-5-nitrophenyl)guanidine (3i)}

The product was synthesized by the reaction of $\mathbf{1}$ and (2-methyl-5-nitrophenyl)guanidine (2i). It was obtained as a brownish white solid. FT-IR $\left(\mathrm{KBr}, \mathrm{cm}^{-1}\right): 3170(\mathrm{~N}-\mathrm{H}), 3020(\mathrm{Ar}-\mathrm{H}), 1670(\mathrm{C}=\mathrm{N})$, $1447(\mathrm{C}=\mathrm{C}), 1314(\mathrm{C}-\mathrm{S}) .{ }^{1} \mathrm{H}$ NMR $\left(\mathrm{DMSO}_{-} \mathrm{d}_{6}\right) \delta \mathrm{ppm}: 2.32\left(\mathrm{~s}, 3 \mathrm{H}, \mathrm{CH}_{3}\right), 2.48\left(\mathrm{~s}, 3 \mathrm{H}, \mathrm{CH}_{3}\right), 5.24(\mathrm{~s}$, 1H, NH), $7.12(\mathrm{~d}, 1 \mathrm{H}, \mathrm{Ar}-\mathrm{H}), 7.21(\mathrm{~d}, 2 \mathrm{H}, \mathrm{Ar}-\mathrm{H}), 7.34(\mathrm{~s}, 1 \mathrm{H}, \mathrm{Ar}-\mathrm{H}), 7.61(\mathrm{~d}, 1 \mathrm{H}, \mathrm{Ar}-\mathrm{H}), 7.71(\mathrm{~d}, 2 \mathrm{H}$, Ar-H), $7.95(\mathrm{~s}, 1 \mathrm{H}, \mathrm{CH}=\mathrm{N}), 9.21(\mathrm{~s}, 1 \mathrm{H}, \mathrm{NH})$. MS (ESI) $m / z$ : 329.12. Anal. Calcd. for $\mathrm{C}_{16} \mathrm{H}_{16} \mathrm{~N}_{4} \mathrm{O}_{2} \mathrm{~S}$ (in \%): C, 58.52; H, 4.91; N, 17.06. Found: C, 58.41; H, 4.80; N, 17.26.

\subsection{Antibacterial activity}

Broth dilution assay was carried out according to the method developed ${ }^{24-26}$ in a microtitre plate (96 well plate) with slight modifications. In brief overnight culture of the above mentioned pathogens were made every time in Muller Hinton's broth and were diluted with the fresh Muller Hinton's broth till the $\mathrm{A}_{600}$ reaches $0.05 .100 \mu \mathrm{l}$ of the each diluted bacterial cultures $\left(\mathrm{A}_{600}=0.05\right)$ were dispensed to their respective wells (96 well polypropylene micro titer plate) in triplicates. A blank is maintained 
which contains only sterile Muller Hinton's broth. The plates were covered with sterile aluminum foil to avoid contamination and were incubated at $37^{\circ} \mathrm{C}$ for $18 \mathrm{hr}$ in a refrigerated bacteriological incubator. The plate was read in UV-Visible microplate spectrophotometer at $600 \mathrm{~nm}$ (photometric) with 10 seconds of shaking; the values obtained for each pathogen and drug of different concentrations were averaged and are negative with the empty broth (Blank). The minimal inhibitory concentration (MIC) was determined by broth microdilution method. The MIC value was defined as the lowest concentration of compounds whose absorbance was comparable with the negative control wells (broth only, without inoculum). MIC values and comparison with standard antibiotic (Carbenicillin) were tabulated as the mean of three replicates.

\subsection{Antioxidant activity}

\subsubsection{DPPH radical scavenging assay}

The free radical scavenging activity was measured by 2,2-diphenyl-1-picrylhydrazyl (DPPH) assay according to the method described earlier. ${ }^{27-29}$ The stock solution was prepared by dissolving $24 \mathrm{mg}$ DPPH with $100 \mathrm{ml}$ methanol and stored at $20^{\circ} \mathrm{C}$ until required. The working solution was obtained by diluting DPPH solution with methanol to attain an absorbance of about $0.98 \pm 0.02$ at $517 \mathrm{~nm}$ using the spectrophotometer. A $3 \mathrm{ml}$ aliquot of this solution was mixed with $100 \mu \mathrm{l}$ of the sample at various concentrations $(20-100 \mu \mathrm{g} / \mathrm{ml})$. The reaction mixture was shaken well and incubated in the dark for $15 \mathrm{~min}$ at room temperature. Then the absorbance was taken at $517 \mathrm{~nm}$. The control was prepared as above without any sample. Ascorbic acid (Vit-C) was used as positive control. All the experiments were done in triplicates and the values are averaged. A dose responsive curve was plotted to determine the $\mathrm{IC}_{50}$ values. $\mathrm{IC}_{50}$ is defined as the concentration sufficient to obtain $50 \%$ of a maximum scavenging capacity. ${ }^{30}$ All the tests were run in triplicate and averaged.

Scavenging effect $(\%)=[($ control absorbance - sample absorbance $) /$ control absorbance $] \times 100$

\subsubsection{Ferrous ion chelating assay}

The chelating activity of the Schiff base derivatives for ferrous ions $\left(\mathrm{Fe}^{2+}\right)$ was measured according to the method. ${ }^{31}$ Briefly, $0.5 \mathrm{~mL}$ different concentration of synthesized compounds was added to a solution of $2 \mathrm{mM} \mathrm{FeCl}_{2}(0.05 \mathrm{~mL})$. The reaction was initiated by the addition of $5 \mathrm{mM}$ ferrozine $(0.2 \mathrm{~mL})$. The mixture was shaken vigorously and left at room temperature for $10 \mathrm{~min}$. Ferrozine reacted with the divalent iron to form stable magenta complex species that were very soluble in water. Absorbance of the solution was then measured spectrophotometrically at $562 \mathrm{~nm}$. EDTA was used as a positive control. All the experiments were done in triplicates and the values are averaged. A dose responsive curve was plotted to determine the $\mathrm{IC}_{50}$ values. $\mathrm{IC}_{50}$ is defined as the concentration sufficient to obtain $50 \%$ of a maximum scavenging capacity. ${ }^{32}$ All the tests were run in triplicate and averaged. The percentage inhibition of ferrozine- $\mathrm{Fe}^{2+}$ complex formation by the compounds was calculated as:

$$
\text { Percentage of inhibition }(\%)=\left[\left(\mathrm{A}_{0}-\mathrm{A}_{1}\right) / \mathrm{A}_{0}\right] \times 100 \text {, }
$$

where $\mathrm{A}_{0}$ was the absorbance of the control, and $\mathrm{A}_{1}$ was the absorbance of the test sample.

\subsection{Cytotoxicity assay}

\subsubsection{Isolation of human peripheral lymphocytes}

The peripheral lymphocytes were isolated from 10 to $15 \mathrm{ml}$ of the freshly drawn venous blood from healthy male donors aged between 22-26 years. Blood was collected in anticoagulant Acid Citrate Dextrose (ACD) (85 mM citric acid, $71 \mathrm{mM}$ Trisodium Citrate, $165 \mathrm{mM}$ D-Glucose) in the ratio of 5:1. To this four volumes of hemolysing buffer $\left(0.85 \% \mathrm{NH}_{4} \mathrm{Cl}\right.$ in $10 \mathrm{mM}$ Tris buffer, $\left.\mathrm{pH} 7.4\right)$ was added, 
mixed well and incubated at $4{ }^{0} \mathrm{C}$ for $30 \mathrm{~min}$. Then the cells were centrifuged at $12000 \mathrm{rpm}$ for $12 \mathrm{~min}$, the supernatant was discarded, pellet was washed thrice with $10 \mathrm{ml}$ of Hanks Balanced Salt Solution (HBSS) (137 mM NaCl, $5 \mathrm{mM} \mathrm{KCL}, 8.5 \mathrm{mM}$ Phosphate buffer $\mathrm{pH}$ 7.4, $0.8 \mathrm{~mm} \mathrm{MgSo} 4$ and $5 \mathrm{mM}$ DGlucose) and suspend in the same buffer solution. Cells were suspended in HBSS and it is stored at 4 ${ }^{0} \mathrm{C} .{ }^{33}$

\subsubsection{Cell viability test}

The cell viability was determined by Tryphan blue dye exclusion method. To $10 \mu 1$ of the cell suspension (Peripheral lymphocytes) an equal volume of $0.4 \%$ tryphan blue was added. The cells were then charged to hemocytometer and the cell number was counted. The dead cells being permeable to tryphan blue appeared blue against white colour of the viable cells. The percent cell viablity was calculated using the formula:

$$
\text { Percent of viability }=[\text { No. of viable cells/Total no. of cells }] \times 100
$$

\section{Results and discussion}

\subsection{Chemistry}

The Schiff bases of 4-(methylthio)benzaldehyde derivatives 3(a-i) were synthesized according to Scheme 1. Formation of Schiff bases of 4-(methylthio)benzaldehyde derivatives 3(a-i) was confirmed by recording their ${ }^{1} \mathrm{H}$ NMR, LC-MS, Elemental analysis FT-IR and UV-visible spectra. The synthesis employs readily available starting materials and simple procedures making this method very attractive and convenient for the synthesis of various Schiff bases compounds. The chemical structures and physical data of all the synthesized compounds are tabulated in Table 1 and Table 2, respectively.

Table 1. Chemical structure of the synthesized compounds 3(a-i)

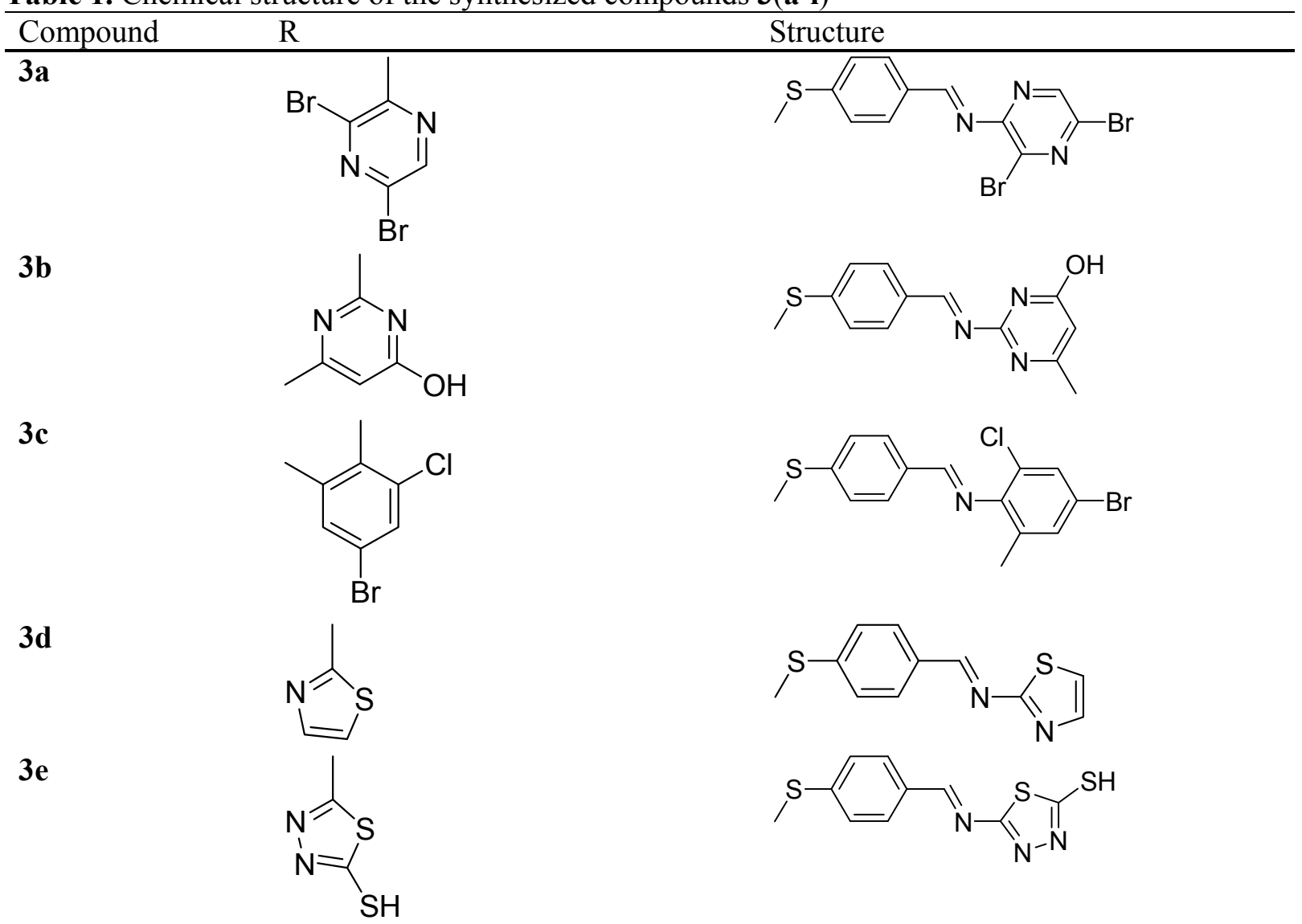


<smiles>Cc1cc(Cl)ccn1</smiles>

$3 g$<smiles>Cc1ncc(C(F)(F)F)cc1Cl</smiles>

3h<smiles>Cc1ccc(C)c(Nc2nccc(-c3ccncc3)n2)c1</smiles>

$3 \mathbf{i}$<smiles>CC(=N)Nc1cc([N+](=O)[O-])ccc1C</smiles><smiles>CSc1ccc(/C=N/c2cc(Cl)ccn2)cc1</smiles><smiles>CSc1ccc(/C=N/c2ncc(C(F)(F)F)cc2Cl)cc1</smiles><smiles>CSc1ccc(/C=N/c2ccc(C)c(Nc3nccc(-c4ccncc4)n3)c2)cc1</smiles><smiles>CSc1ccc(/C=N/C(=N)Nc2cc([N+](=O)[O-])ccc2C)cc1</smiles>

Table 2. Physical data of the synthesized compounds 3(a-i)

\begin{tabular}{lllll}
\hline Compound & UV-visible $(\mathrm{nm})$ & M.P. $\left({ }^{\circ} \mathrm{C}\right)$ & Solubility & Yield (\%) \\
\hline $\mathbf{3 a}$ & 381 & $126-129$ & Ethyl acetate & 78.60 \\
$\mathbf{3 b}$ & 258 & $135-137$ & Ethanol & 71.85 \\
$\mathbf{3 c}$ & 295 & $110-112$ & Ethanol & 79.36 \\
$\mathbf{3 d}$ & 244 & $128-130$ & Ethyl acetate & 68.21 \\
$\mathbf{3 e}$ & 253 & $114-116$ & Ethyl acetate & 75.98 \\
$\mathbf{3 f}$ & 310 & $121-122$ & Ethanol & 81.23 \\
$\mathbf{3 g}$ & 271 & $92-94$ & Ethanol & 68.23 \\
$\mathbf{3 h}$ & 389 & $138-140$ & Ethyl acetate & 68.20 \\
$\mathbf{3 i}$ & 374 & $142-145$ & DMF & 68.26 \\
\hline
\end{tabular}

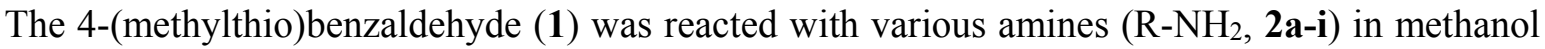
to obtain Schiff bases of 4-(methylthio)benzaldehyde derivatives 3(a-i) in good yield (68-82\%). The UV spectra of 3(a-i) were recorded using suitable solvents in the range of $200-800 \mathrm{~nm}$. The electronic absorption spectra of compounds show new bands and appearance of wavelength absorption band in the UV region in UV-visible spectrum owing to confirms the formation of new compounds. The FTIR spectra of 3(a-i) were recorded using $\mathrm{KBr}$ pellets in the range of $4000-400 \mathrm{~cm}^{-1}$. The absence of $\mathrm{NH}_{2}$ and $\mathrm{C}=\mathrm{O}$ absorption bands in the IR spectra confirmed that the synthesized compounds. The absorption bands at $3060-3080 \mathrm{~cm}^{-1}$ are assigned to the aromatic- $\mathrm{H}$ stretch. The absorption band at $1728 \mathrm{~cm}^{-1}$ is due to the $\mathrm{HC}=\mathrm{O}$ stretch in compound $\mathbf{1}$. The appearance of a medium to strong absorption bands at $1659-1676 \mathrm{~cm}^{-1}$ due to a stretching vibration of the azomethine $(\mathrm{HC}=\mathrm{N})$ bond formation in the synthesized compound. The strong bands at $527 \mathrm{~cm}^{-1}$ and $521 \mathrm{~cm}^{-1}$ are assigned to the $\mathrm{C}$-Br stretch in 3a and 3c, respectively. New bands appeared at $\left.1106 \mathrm{~cm}^{-1} \mathbf{( 3 g}\right)$ corresponding to $\mathrm{C}-\mathrm{F}$ stretching frequency. The strong bands at $728 \mathrm{~cm}^{-1}$ and $714 \mathrm{~cm}^{-1}$ are assigned to the $\mathrm{C}-\mathrm{Cl}$ stretch in $\mathbf{3 c}$ and $\mathbf{3 f}$, respectively. The characteristic resonance peaks in ${ }^{1} \mathrm{H}$ NMR for the new compounds were reported using DMSO- $\mathrm{d}_{6}$. The proton spectral data agree with respect to the number of protons and their chemical shifts with the proposed structures. The proton spectral data of the starting material, 4(methylthio)benzaldehyde (1) shows resonance at $\delta 10.08 \mathrm{ppm}(\mathrm{s}, 1 \mathrm{H}, \mathrm{CHO})$. In all the synthesized compounds 3(a-i) the above resonance disappeared and additional resonances assigned to the $-\mathrm{CH}=\mathrm{N}$ $(\delta 7.95-8.80 \mathrm{ppm})$ were observed which confirmed the product. The mass spectra of 3a showed molecular ion peak at m/z 387.80 which is in agreement with the molecular formula $\mathrm{C}_{12} \mathrm{H}_{9} \mathrm{Br}_{2} \mathrm{~N}_{3} \mathrm{~S}$. The 
elemental analyses data showed good agreement between the experimentally determined values and the theoretically calculated values within $\pm 0.4 \%$.

\subsection{Biology}

The investigation of antibacterial screening data revealed that all tested compounds showed antibacterial activity against four pathogenic bacterial strains. Among the series $\mathbf{3 a} \mathbf{a} \mathbf{i}$, compounds $\mathbf{3 g}$, 3h and 3i exhibited a significant antibacterial activity against Gram positive and Gram negative bacteria. Compounds $\mathbf{3 c}, \mathbf{3 e}, \mathbf{3 g}$ and $\mathbf{3 d}$ showed good zone of inhibition against tested bacterial strains in comparison to standard drug. Compounds $\mathbf{3 a}, \mathbf{3 f}$ and $\mathbf{3 b}$ showed moderate inhibitory activity against tested bacterial strains. The Percentage of inhibition and MIC results were compared with standard drug Carbenicillin as depicted in Table 3 and Table 4 respectively. Compound $\mathbf{3 h}$ was found to be more potent against gram positive and gram negative bacterial strains with the $94-99 \%$ (at $500 \mu \mathrm{g}$ ) zone of inhibition. The nature of the linkage (substituent on aromatic ring) influences the antibacterial activity. Compounds 3a-i showed antibacterial activity in the order: $\mathbf{3 h}>\mathbf{3 i}>\mathbf{3 g}>\mathbf{3 e}>\mathbf{3 c}>\mathbf{3 d}>\mathbf{3 a}>\mathbf{3 f}>\mathbf{3 b}$ against tested bacterial strains (Fig.1). However, the activities of the tested compounds are less than those of standard antibacterial agents used.

Table 3. Percentage inhibition of the tested compounds

\begin{tabular}{lllll}
\hline Compound & \multicolumn{4}{c}{ \% of bacterial growth inhibition $(500 \mu \mathrm{g} / \mathrm{ml})$} \\
\cline { 2 - 5 } & E.Coli & P.Fluorescence & M.Luteus & B.Subtilis \\
\hline 3a & 51.84 & 42.86 & 44.55 & 46.91 \\
3b & 46.99 & 36.31 & 37.63 & 38.75 \\
3c & 65.10 & 60.12 & 57.74 & 55.24 \\
3d & 60.94 & 58.24 & 50.19 & 53.13 \\
3e & 69.96 & 65.05 & 61.87 & 60.16 \\
3f & 50.72 & 41.21 & 43.73 & 39.42 \\
3g & 90.44 & 87.90 & 94.87 & 93.82 \\
3h & 94.91 & 98.67 & 96.88 & 97.84 \\
3i & 93.40 & 93.38 & 96.18 & 96.92 \\
Standard & 96.29 & 98.49 & 97.58 & 98.60 \\
\hline
\end{tabular}

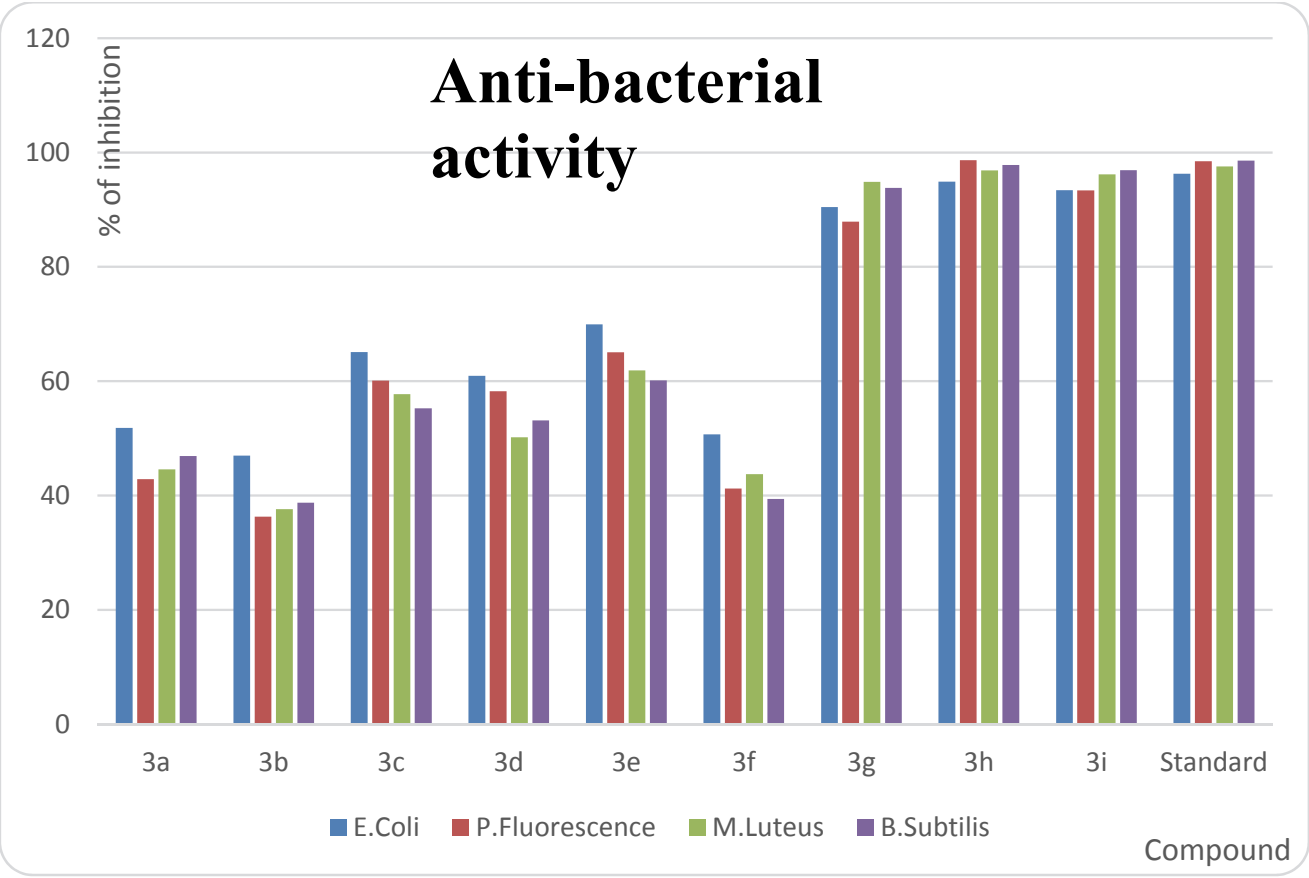

Fig. 1. Anti-bacterial activity of the tested compounds 
Table 4. MIC of the tested compounds

\begin{tabular}{lcccc}
\hline Compound & \multicolumn{4}{c}{ \% of bacterial growth inhibition $(500 \mu \mathrm{g} / \mathrm{ml})$} \\
\cline { 2 - 5 } & E.Coli & P.Fluorescence & M.Luteus & B.Subtilis \\
\hline 3a & 320 & 360 & 350 & 340 \\
3b & 340 & 410 & 400 & 390 \\
3c & 120 & 150 & 180 & 275 \\
3d & 150 & 175 & 300 & 150 \\
3e & 110 & 120 & 140 & 425 \\
$\mathbf{3 f}$ & 335 & 370 & 361 & 30 \\
$\mathbf{3 g}$ & 40 & 50 & 25 & 15 \\
$\mathbf{3 h}$ & 20 & 10 & 15 & 20 \\
3i & 25 & 15 & 20 & 13 \\
Standard & 16 & 08 & 12 & \\
\hline
\end{tabular}

The compound $\mathbf{3 b}$ showed higher radical inhibition activity due to the presence of hydroxy group (electron donating group) in the aromatic ring. ${ }^{34}$ Percentage of DPPH radical scavenging activity and $\mathrm{IC}_{50}$ values were depicted in Table 5.

Table 5. DPPH radical scavenging activity of the tested compounds

\begin{tabular}{|c|c|c|c|c|c|c|}
\hline \multirow[t]{3}{*}{ Compounds } & \multicolumn{5}{|c|}{$\%$ of Scavenging activity } & \multirow{3}{*}{$\begin{array}{c}\mathrm{IC}_{50} \\
(\mu \mathrm{g} / \mathrm{ml})\end{array}$} \\
\hline & \multicolumn{5}{|c|}{ Concentrations $(\mu \mathrm{g})$} & \\
\hline & 20 & 40 & 60 & 80 & 100 & \\
\hline $3 a$ & 58 & 62 & 68 & 70 & 78 & 17.24 \\
\hline $3 b$ & 12 & 15 & 45 & 48 & 50 & 100.00 \\
\hline $3 c$ & 54 & 59 & 64 & 68 & 74 & 18.51 \\
\hline 3d & 48 & 52 & 56 & 58 & 60 & 38.46 \\
\hline $3 e$ & 46 & 51 & 54 & 57 & 61 & 38.46 \\
\hline 3f & 56 & 59 & 63 & 67 & 75 & 17.85 \\
\hline $3 g$ & 24 & 33 & 41 & 55 & 68 & 72.72 \\
\hline 3h & 24 & 30 & 38 & 41 & 48 & 104.16 \\
\hline $3 \mathbf{i}$ & 15 & 17 & 25 & 32 & 47 & 106.38 \\
\hline Standard & 59 & 61 & 64 & 69 & 74 & 16.94 \\
\hline
\end{tabular}

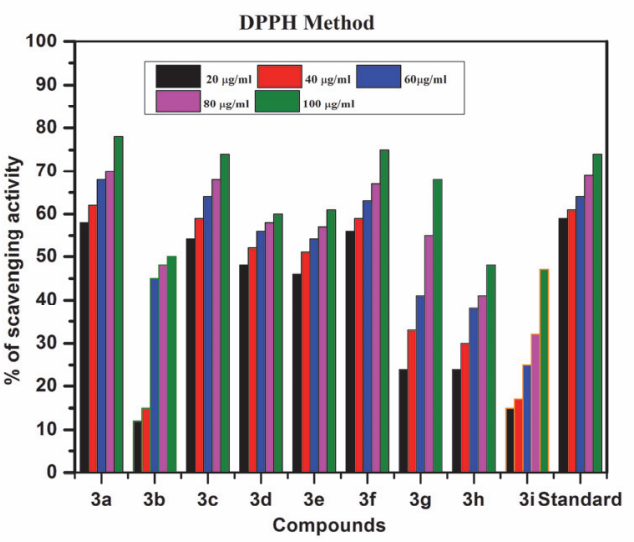

Fig. 2. DPPH radical scavenging activity of the tested compounds

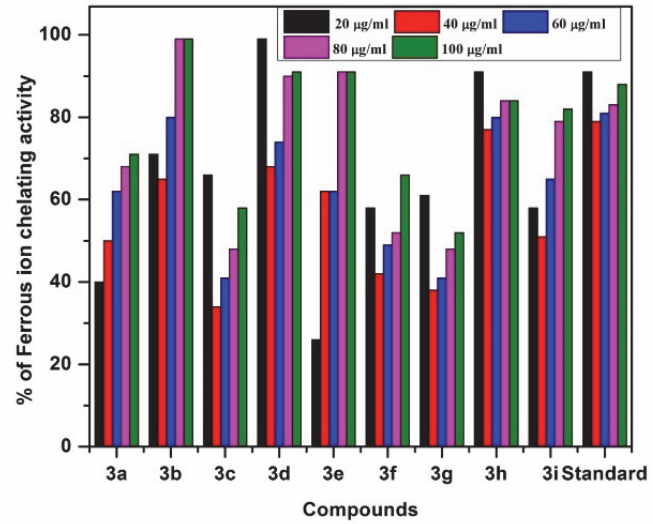

Fig. 3. Ferrous ion chelating activity of the tested compounds

The aromatic ring system with halogens like chlorine or fluorine in $\mathbf{3 c}, \mathbf{3 f}$ and $\mathbf{3 g}$ were found to be more active than other compounds in the series (Fig.2). Thiazole group in $\mathbf{3 d}$ and thiadiazole group in $\mathbf{3 e}$ are found to be similar antioxidant activity. Compounds $\mathbf{3 a}, \mathbf{3 h}$ and $\mathbf{3 i}$ showed moderate antioxidant activity. The nature of the functional groups is crucial for biological activity. All the investigated substances were capable of chelating $\mathrm{Fe}^{2+}$ ions. $\mathrm{Fe}^{2+}$ ions initiate free radicals through the Fenton and Haber-Weiss reaction. Fenton Weiss reaction is a reaction between ferrous ion and hydrogen peroxide which produces highly reactive hydroxyl radicals implicated in many diseases. ${ }^{35}$ The metal chelating 
effects of the samples were dependent on concentration and linearly increased with the sample concentration increased. The affinity of 3a-i for ferrous ions was relatively low comparison to EDTA (Fig.3). However the activity of $\mathbf{3 b}$ was nearer to standard. Thiazole group in $\mathbf{3 d}$ and thiadiazole group in 3e are found to be similar antioxidant activity. The aromatic ring system with halogens like chlorine or fluorine in $\mathbf{3 a}, \mathbf{3 c}, \mathbf{3 f}$ and $\mathbf{3 g}$ were found to be less active than other compounds in the series. Percentage of ferrous ion chelating activity was depicted in Table 6.

Table 6. Ferrous Ion Chelating activity of the tested compounds

\begin{tabular}{|c|c|c|c|c|c|c|}
\hline \multirow[t]{3}{*}{ Compounds } & \multicolumn{5}{|c|}{$\%$ of Ferrous ion chelating activity } & \multirow[t]{3}{*}{$\mathrm{IC}_{50}$} \\
\hline & \multicolumn{5}{|c|}{ Concentrations $(\mu \mathrm{g})$} & \\
\hline & 20 & 40 & 60 & 80 & 100 & \\
\hline $3 \mathbf{a}$ & 40 & 50 & 62 & 68 & 71 & 40.00 \\
\hline 3b & 66 & 65 & 80 & 99 & 99 & 15.15 \\
\hline $3 c$ & 26 & 34 & 41 & 48 & 58 & 83.33 \\
\hline 3d & 61 & 68 & 74 & 90 & 91 & 16.12 \\
\hline $3 e$ & 58 & 62 & 62 & 91 & 91 & 16.24 \\
\hline 3f & 34 & 42 & 49 & 52 & 66 & 61.22 \\
\hline $3 g$ & 32 & 38 & 41 & 48 & 52 & 83.33 \\
\hline $3 h$ & 32 & 77 & 80 & 84 & 84 & 25.97 \\
\hline $3 \mathbf{i}$ & 42 & 51 & 65 & 79 & 82 & 39.21 \\
\hline Standard & 72 & 79 & 81 & 83 & 88 & 13.88 \\
\hline
\end{tabular}

Toxicity study is the most important aspect of the new drug development program as far as the safety evaluation is concerned. Therefore, an attempt was made to determine the cytotoxicity by Tryphan blue exclusion method, which was very simple $\&$ precise. Tryphan blue exclusion method is based on the ability of viable cells to be impermeable to Tryphan blue. The inhibition percentage with regard to cytotoxicity of compounds was found to be 50-90\%. Percentage of cell viability of peripheral lymphocytes was depicted in Table 7 . From this study, it was observed that compounds $\mathbf{3 h}$ and $\mathbf{3 b}$ are shown to be more cytotoxicity activity, may be the presence of pyrimidine. Compounds $\mathbf{3 f}$ and $\mathbf{3 g}$ showed moderate to good cytotoxicity against normal peripheral lymphocytes. Compound $\mathbf{3 i}$ exhibited more active when compared to $\mathbf{3 a}, \mathbf{3 d}$ and $\mathbf{3 e}$.

Table 7. Cytotoxicity activity of the tested compounds

\begin{tabular}{lc}
\hline Compound & \% of viable cells \\
\hline 3a & 54 \\
$\mathbf{3 b}$ & 80 \\
$\mathbf{3 c}$ & 59 \\
$\mathbf{3 d}$ & 51 \\
$\mathbf{3 e}$ & 50 \\
$\mathbf{3 f}$ & 71 \\
$\mathbf{3 g}$ & 69 \\
$\mathbf{3 h}$ & 90 \\
$\mathbf{3 i}$ & 66 \\
Control & 95 \\
Mitomycin C & 93 \\
Toluene & 43 \\
CuSO & 37 \\
\hline
\end{tabular}

\section{Conclusion}

In conclusion, a series of Schiff bases of 4-(methylthio)benzaldehyde derivatives 3(a-i) were synthesized in good yield, characterized by different spectral studies and their biological activity has been evaluated. Compounds $\mathbf{3 g}, \mathbf{3 h}$ and $\mathbf{3 i}$ exhibited a significant antibacterial activity against Gram positive and Gram negative bacteria. The compound $\mathbf{3 b}$ showed higher radical inhibition and $\mathrm{Fe}^{2+}$ chelating activity. Compounds $\mathbf{3 h}$ and $\mathbf{3 b}$ are shown to be more cytotoxicity activity. The in-vitro 
cytotoxity assay offer quick, simple and efficient way of testing the toxicity and forms an important tool for high throughput screening of synthesized compounds.

\section{Acknowledgements}

One of the authors (Karthik C. S.) is grateful to University Grants Commission (UGC), New Delhi for financial support under UGC-JRF (F.No.42-366/2013 (SR) dated 25.03.13).

\section{References}

1 Romashkina, R.B., Majouga, A.G., Beloglazkina, E.K., Pichugina, D.A., Askerka, M.S., Moiseeva, A.A., Zyk, N.V. (2012) Sulfur-containing terpyridine derivatives: synthesis, coordination properties and adsorption on the gold surface. Russ. Chem. Bull., 61 (12) $2265-$ 2281.

2 Battilocchio, C., Poce, G., Alfonso, S., Porretta, G.C., Consalvi, S., Sautebin, L., Biava, M. A. (2013) Class of pyrrole derivatives endowed with analgesic/anti-inflammatory activity. Bioorg. Med .Chem ., 21 (13) 3695-3701.

3 Appelbaum, P.C., Hunter, P.A. (2000) The fluoroquinolone antibacterials: past, present and future perspectives. Int. J. antimicrob agents., 16 (1) 5-15.

4 Ball, P. (2000) Quinolone generations: natural history or natural selection. J. Antimicrob Chemoth., 46 (3) 17-24.

5 Andriole, V.T. (1999) Current and future antifungal therapy. New targets for antifungal agents. J. Antimicrob Chemoth ., 44 (2) 151-162.

6 Frere, J.M. (1995) Beta-lactamases and bacterial resistance to antibiotics. Mol. Microb., 16(3), 385-395.

7 Lau, K.Y., Mayr, A., Cheung, K.K. (1999) Synthesis of transition metal isocyanide complexes containing hydrogen bonding sites in peripheral locations. Inorg. Chimica. Acta., 285 (2) 223232.

8 Shawali, A.S., Harb, N.M.S., Badahdah, K.O. (1985) A study of tautomerism in diazonium coupling products of 4-hydroxycoumarin. J. Heterocyc. Chem., 22 (5) 1397-1403.

9 Raman, N., Muthuraj, V., Ravichandran, S., Kulandaisamy, A. (2003) Synthesis, characterisation and electrochemical behaviour of $\mathrm{Cu}$ (II), $\mathrm{Co}$ (II), Ni (II) and $\mathrm{Zn}$ (II) complexes derived from acetylacetone and p-anisidine and their antimicrobial activity. J. Chem. Sci., 115 (3) 161-167.

10 Sridhar, S.K., Ramesh, A.J. (2002) Synthesis and pharmacological activities of Schiff bases and hydrazones of isatin derivatives. Indian. Chem. Soc., 41, 668.

11 Przybylski, P., Brzezinski, B. (2002) Spectroscopic studies and PM3 semiempirical calculations of Schiff bases of gossypol with L-amino acid methyl esters. Biopoly., 67 (1) 6169.

12 Sari, N., Arslan, S., Logoglu, E., Sariyan, I. (2003) Metal-based antibacterial and antifungal agents: synthesis, characterization, and in vitro biological evaluation of Co (II), Cu (II), Ni (II), and $\mathrm{Zn}$ (II) complexes with amino acid-derived compounds. G.U.J. Sci., 16, 283-287.

13 Capdeville, R., Buchdunger, E., Zimmermann, J., Matter, A. (2002) Glivec (STI571, imatinib), a rationally developed, targeted anticancer drug. Nat. Rev. Drug. Dis., 1 (7) 493-502.

14 Cheeseman, K.H., Slater, T.F. (1993) Free radical in medicine, Churchill Livingstone, New York.

15 Mitchell, R.N., Cotran, R.S. (2003). Basic Pathology $7^{\text {th }}$ edn. Harcourt (India) Pvt Ltd, New Delhi, 3-33.

16 Hall, C.A., Cuppett, S.L. (1997) Structure-activities of natural antioxidants. Antioxidant methodology in vivo and in vitro concepts, Champaign, IL: AOCS press, 2-29.

17 Hudson, B.J.F. (1990) Food Antioxidants. Elsevier Applied Science London.

18 Gugumus, F. (1990) Oxidation Inhibition in Organic Materials. CRC Press Boca Raton Florida USA. 
19 Pospisil, J., Horak, Z., Pilar, J., Billingham, N.C., Zweifel, H., Nespurek, S. (2003) Influence of testing conditions on the performance and durability of polymer stabilisers in thermal oxidation. Poly. Degrad. Stab., 82 (2) 145-162.

20 Sies, H. (1997) Oxidative stress: oxidants and antioxidants. Exp. Physiol., 82, 291-295.

21 Vertuani, S., Angusti, A., Manfredini, S. (1997) The antioxidants and pro-antioxidants network: an overview. Curr. Pharm. Des, 10, 1677-1694.

22 Lillie, R.D. Ed. H.J. (1977) Conn's Biological Stains, 9th Edn, The Williams and Wilkins Company.

23 Sanjay Patel., Nirav Gheewala., Ashok Suthar., Anand Shah. (2009) In-vitro cytotoxicity activity of solanum nigrum extract against hela cell line and vero cell line. Int. J. Pharm Pharm. Sci., 1 (1) 38-46.

24 Malgorzata Cytrynska., Pawel Mak., Agnieszka Zdybika-Barabas., Piotr Suder., Teresa Jakubowicz, (2007) Purification and characterization of eight peptides from galleria mellonella immune hemolymph. Peptides., 28, 533-546.

25 Hwang., Jae-Sam., Juneyoung Lee., Bomi Hwang., Sung-Hee Nam., Eun-Young Yun., SeongRyul Kim., Dong Gun Lee. (2010) Isolation and characterization of psacotheasin, a novel Knottin-type antimicrobial peptide from Psacothea hilaris. J. Microbiol. Biotech., 20 (4) 708711.

26 Jae-Sam., Hwang., juneyoung Lee., Yeon-Ju Kim., Hea-Son Bang., Eun-Young Yun., SeongRyul Kim., Jae-Pil Jeon., Dong Gun Lee, (2009) Isolation and characterization of a defensinlike peptide (Coprisin) from dung beetle, copris tripartitus. Int. J. Pep., Article ID 136284.

27 Brand-Williams, W., Cuvelier, M.E., Berset, C. (1995) Use of free radical method to evaluate antioxidant activity. Lebensmittel-Wissenschaft und-Technol., 28, 25-30.

28 Bursal, E., Gulcin, I. (2011) Polyphenol contents and in vitro antioxidant activities of lyophilized aqueous extract of kiwifruit (Actinidia deliciosa). Food. Res. Int., 44, 1482-1489.

29 Saeed, N., Khan, M. R., Shabbir, M. (2012) Antioxidant activity, total phenolic and total flavonoid contents of whole plant extracts torilis leptophylla L. BMC. Compl. Alternat. Med., 12 (1) 221-225.

30 Kumaraswamy, M.V., Satish, S. (2008) Antioxidant and anti-lipoxygenase activity of the spesia lampas dalz and gibs. Adv. Bio. Res., 2 (3) 56-59.

31 Dinis, T.C., Madeira, V.M., Almeida, L.M. (1994) Action of phenolic derivatives (acetaminophen, salicylate and 5-aminosalicylate) as inhibitors of membrane lipid peroxidation and as peroxyl radical scavengers. Arch. Biochem. Biophys., 315 (1) 161-169.

32 Rao, R.P., Gowda, S.S., Leela, S. (2006) Smoke treatment trigerrs the release of a novel DNA damaging factor by lymphocytes. Mol. Cell. Biochem., 284, 73-79.

33 Phillips, H.J. (1973) Dye exclusion tests for cell viability. Tissue culture: methods and applications, 406-408.

34 Mallesha, L., Mohana, K., Veeresh, B. (2010) Synthesis and biological activities of Schiff bases of gabapentin with different aldehydes and ketones: a structure-activity relationship study. Med. Chem. Res., DOI 10.1007/s00044-010-9498-8.

35 Lloyd, R.V., Hanna, P.M., Mason, R.P. (1997) The origin of the hydroxyl radical oxygen in the Fenton reaction. Free. Radical. Bio. Med., 22, 885-888. 